\title{
The integration of multiple intelligences theory and TAI cooperative learning for teaching Calculus for Engineering 1 for bachelor's degree students
}

\author{
Chanokgan Sahatsathatsana $^{1}$, Sattra Sahatsathatsana ${ }^{2}$, Wirawan Heman ${ }^{3}$ \\ ${ }^{1,3}$ Department of Science and Mathematics, Faculty of Science and Health Technology, Kalasin University, \\ Kalasin, Thailand \\ ${ }^{2}$ Department of Foreign Languages, Faculty of Liberal Arts, Kalasin University, Kalasin, Thailand
}

\begin{tabular}{|c|c|}
\hline Article Info & ABSTRACT \\
\hline Article history: & \multirow{10}{*}{$\begin{array}{l}\text { The purposes of this study were (1) to compare the pre and post-tests scores of } \\
\text { learning through the developed lesson plans based on the theory of multiple } \\
\text { intelligences and TAI cooperative learning, and (2) to evaluate the students' } \\
\text { satisfaction on learning through the developed lesson plans based on the theory } \\
\text { of multiple intelligences and TAI cooperative learning. The subjects were } 41 \\
\text { students of the Faculty of Engineering and Industrial Technology who enrolled } \\
\text { in the Calculus for Engineering } 1 \text { subject in the first semester of the } 2019 \\
\text { academic year received from cluster random sampling. The research instruments } \\
\text { were lesson plans, learning achievement test, and a questionnaire on students } \\
\text { satisfaction. The results revealed that: the mean score of the post-test on the topic } \\
\text { of differentiation of algebraic functions was significantly higher than mean score } \\
\text { of the pre-test at the level of .05. The mean score of the students' satisfaction on } \\
\text { learning through the developed lesson plans was at the highest level. }\end{array}$} \\
\hline Received September 16, 2021 & \\
\hline Revised December 10, 2021 & \\
\hline Accepted December 15, 2021 & \\
\hline & \\
\hline Keywords: & \\
\hline Calculus for Engineering & \\
\hline cooperative learning & \\
\hline multiple intelligences & \\
\hline TAI & \\
\hline
\end{tabular}

This is an open access article under the CC BY-SA license.

\section{Corresponding Author:}

Chanokgan Sahatsathatsana

Deaperment of Science and Mathematics

Faculty of Science and Health Technology

Kalasin University

Thailand

Email: Chanokgan.na@ksu.ac.th

\section{INTRODUCTION}

Research on teaching and learning of mathematics has become an area of research focusing on the teaching of mathematics in the past decade. Studies have indicated that teachers need to equip themselves with more flexible approaches (Galton \& Eggleston, 1979) in the teaching of mathematics. The teaching and learning of mathematics is no longer regarded as only a simple and technical procedure involving teaching objectives and learning outcomes. Teachers are encouraged to adopt progressive teaching styles to accommodate the varied abilities of students, in order to enable these students to excel in their learning. Consequently, the teaching methods for teaching mathematics should be focused on serving the needs of learners by establishing a suitable learning environment for students.

For mathematics teaching and learning, students are not only required to have knowledge of numerical facts, but also be adept in problem solving that are adjustable in accordance with their individual strength and weaknesses (Jones \& Tanner, 2002). So, lessons in mathematics should be structured into three parts: a mental and oral introduction, the main teaching and activity and a conclusion. Effective teaching of mathematics does not depend on a fixed structure of instructional strategy but involves with a lively and interactive two-way process in 
which students play an active part by answering questions and engaging in discussions, explaining and demonstrating their methods to others in the class where a rich set of teaching strategies is required from the teachers to ensure the effectiveness of the lesson (Sulaiman et.al., 2010).

Calculus for Engineer 1 is the subject that helps to improve the thinking process and allows students to experience the creative thinking for self-problem solving. It is also the fundamental course for further learning in advanced calculus and engineering. However, there were many factors which negatively affected the teaching Calculus for Engineer 1 which resulted in the failure of being successful based on the goals of the subject such as the content of the subject itself which were overwhelming and difficult, the attitude of students towards learning mathematics, teaching time limitation due to the amount and difficulty, and the teachers lack of teaching techniques and materials.

The researchers, therefore, were aware of the importance of the implementation of teaching techniques basing on the individual differences and the cooperative learning giving the students opportunities to develop knowledge, analyze and synthesize information, think creatively and critically, be able to search for information by themselves, to be continuously develop themselves, have working skills, and work with others (Parchagool et.al., 2016). It is utterly challenging for teachers to help students learn mathematics effectively. Teachers have to realize that a single teaching method is insufficient (Sulaiman, 2011). Effective teaching strategies are essential in ensuring a successful teaching and learning process. Individual qualities within each teacher have been recognized as a major influence on their capacity and ability in creating opportunities for their students to learn effectively (Ball \& Perry, 2009).

Discovering the effective teaching strategies that teachers are comfortable with in teaching and students learn with happiness and in a relaxed manner will be beneficial for learning mathematics. It is important to mention that all learning materials should include opportunities for students to develop their strengths and strengthen their weaknesses in each particular intelligence area (Lash, 2004). Therefore, it is necessary to assess the effectiveness of our current teaching style and consider innovative ways to improve our teaching to enhance the teaching and learning effect (Delaney \& Shafer, 2007). Regarding the situation mentioned earlier, the researchers studied the theory of multiple intelligences (MI) of Howard Gardner (1983) basing on the belief of different capabilities and abilities of individuals resulting in the different functions of brain which affect the multiple intelligences in one person.

This theory influenced on the principle of education aiming at developing the students to be complete persons, paying attention to individual differences, developing students based on their actual capabilities and aptitudes, integrating arts, self-awareness, communication, and promoting body language (Ezeh et.al., 2021). According to Gardner (1996), Multiple Intelligences included: Linguistic Intelligence, Logical-Mathematical Intelligence, Spatial Intelligence, Musical Intelligence, Bodily-kinesthetic Intelligence, Interpersonal Intelligence, Intrapersonal Intelligence, Naturalist Intelligence, and Existential Intelligence. The teaching that relates, connects, and integrates multiple intelligences can develop the intelligences of individuals regarding the potential of ones stimulating the learning, reducing the stress, and increasing happiness (Bullough, 2011; Keawchuer, 2014).

The Team Assisted Individualization or TAI is the learning process which integrates the cooperative learning and individualized instruction. It focuses on group work. Each group consists of the multi learning ability including high, medium, and low abilities. The member of each group will be assigned a learning task that suites their learning ability. The members in the group will help each other to learn and work through sharing experiences for improving the learning ability, learning and working skills, and responsibilities (Adams \& Slater, 2002; Peysner, 2021). In regards with the aforementioned, the researchers, as the lecturer in mathematics teaching Calculus for Engineering 1) are interested in studying the learning instruction based on the theory of multiple intelligences integrated with the TAI cooperative learning to improve the students' critical and systematic thinking and mathematics process skills. The developed instruction was based on Limit Calculation included 3 steps which were : 1) Preparation 2) Teaching and 3) Formative and Summative Evaluations as illustrated in Figure 1. 


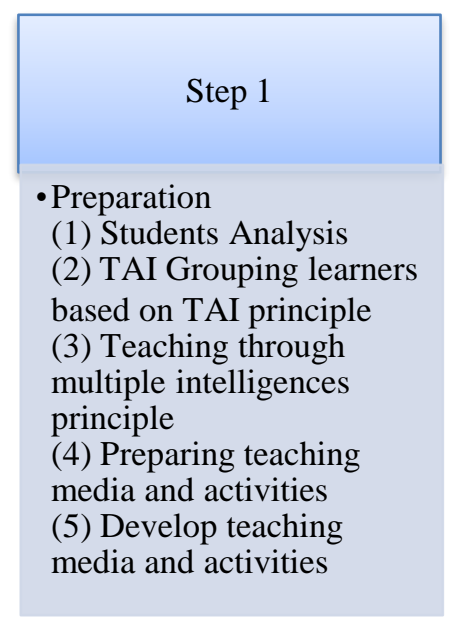

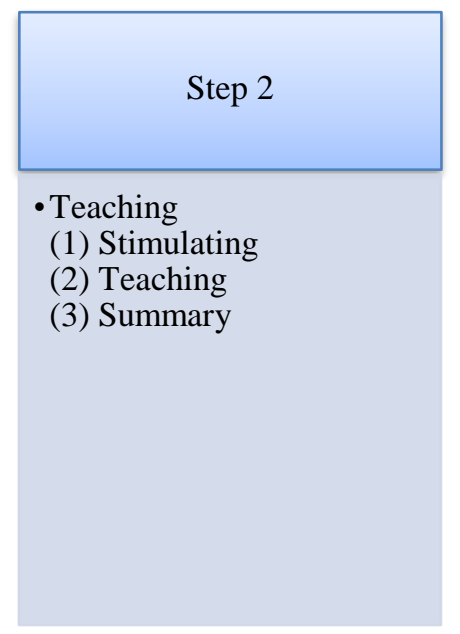

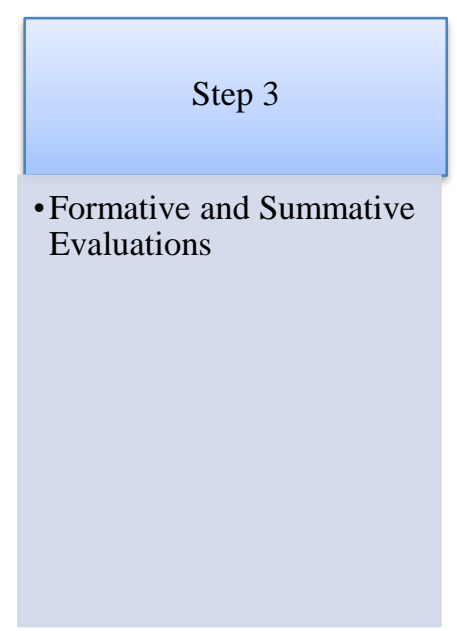

Figure 1 Learning procedures

\section{RESEARCH OBJECTIVE}

(1) To compare the pre and post-tests scores of learning developed lesson plans of Calculus for Engineering 1 subject on differentiation of algebraic functions calculation basing on the theory of multiple intelligences and TAI cooperative learning.

(2) To evaluate the students' satisfaction on learning through the developed lesson plans of Calculus for Engineering 1 subject on differentiation of algebraic functions basing on the theory of multiple intelligences and TAI cooperative learning.

\section{METHOD}

\subsection{Populations and Subjects}

The populations of this study were students of the Faculty of Engineering and Industrial Technology who were enrolled in the Calculus for Engineering 1 subject in the first semester of the 2019 academic year.

The subjects were 41 students of the Faculty of Engineering and Industrial Technology who were enrolled in the Calculus for Engineering 1 subject in the first semester of the 2019 academic year obtained from cluster random sampling.

\subsection{Research Instruments}

There were 4 research instruments used in this study. The development of each instrument is as follows:

1. The lesson plan for teaching Calculus for Engineering 1 subject on differentiation of algebraic functions function calculation which was developed according to the following procedure: 1) studied the course description of the Calculus for Engineering 1 subject and selected the topic for teaching including meaning of vector algebra function, examples of vector algebra function, meaning of integrals calculation, and examples of integrals vector algebra function calculation, 2) studied the theory of multiple intelligences and TAI cooperative learning, 3) developed the lesson plan, 4) tried out the lesson plan with different groups of students, and 5) revised the lesson plan according to problems and inconveniences found during the trials.

2. Learning achievement test of Calculus for Engineering 1 subject on differentiation of algebraic functions consisted of 5 subjective items with 10 points and 30 items of 5 alternatives multiple choice questions with 30 points. The total was 40 points. It was tried out with another group of students to find out the item difficulty and the item discrimination. It was found that the item difficulty was 0.3500 .70 while the item discrimination was 0.86 respectively.

3. The questionnaire on students' satisfaction on learning through the learning activity developed by integrating the theory of multiple intelligences and TAI cooperative learning of Calculus for Engineering 1 subject. It was tried out with another group of students to find out the reliability. It was found the reliability was 0.74 .

\subsection{Research Procedures}

The learning activity in this study were developed by integrating the theory of multiple intelligences and TAI cooperative learning of Calculus for Engineering 1 for Bachelor's degree students which could be divided 
into 3 steps including: 1 (preparation, 2 (teaching, and 3 (formative and summative evaluations which could be described as follow:

\section{Step 1 :Preparation}

(1) Students Analysis: The researchers analyzed the students through the observation, activity participation, interview, and taking the pre-test .The data were summarized for improving the students 'potential.

(2) Choosing high learning ability students: The researchers selected the students who had high learning ability based on the results from the grade of the mathematics subjects learnt in the previous semester and the voluntary of students.

(3) TAI Grouping learners based on TAI cooperative learning principle: The researchers arranged the pretest scores of students in descending order and used it for grouping students .Each group consisted of 4 students including 1 high learning ability student, 2 medium learning ability students, and 1 low learning ability student as illustrated in Figure 2.

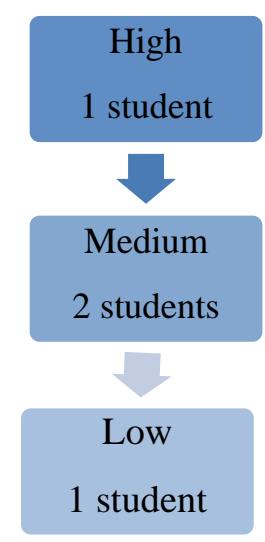

Figure 2 Grouping Process

(4) Teaching through multiple intelligences theory: The researchers developed the lesson plans on of Calculus for Engineering 1 subject on differentiation of algebraic functions calculation based on the theory of multiple intelligences and TAI cooperative learning according to the following steps :1 (studied the course description of the Calculus for Engineering 1 subject 2 (studied the theory of multiple intelligences and TAI cooperative learning 3 (developed the lesson plan 4 (tried out the lesson plan with a different group of students and 5 (revised the lesson plan according to problems and inconveniences found during the trials.

\section{Step 2 :Teaching}

The researcher taught the students through the teaching steps of the developed lesson plans on of Calculus for Engineering 1 subject on differentiation of algebraic functions calculation based on the theory of multiple intelligences and TAI cooperative learning including 1) using questions to stimulate the students' interest in the warm up to relate to the new topic with their prior knowledge, experiences, and expectations, 2) teaching the content by explaining (Linguistic Intelligence), using gestures (Bodily-kinesthetic Intelligence), using numbers (Logical-Mathematical Intelligence), using pictures (Spatial Intelligence), and practicing calculation individually (Intrapersonal Intelligence), and 3) summarizing the learning by working in groups (Interpersonal Intelligence) to present the summary of what they have learned, the importance of what they have learned, how to apply what they have learned to real life situations, how to integrate what they have learned with other subjects, how what they have learned will help them live happily and work successfully (Existential Intelligence) in the future through the mind map of animals or trees (Naturalist Intelligence), and stimulating students to cover famous musical compositions with the content of what they have learned (Musical Intelligence).

\section{Step 3 :Formative and Summative Evaluation}

There were two kinds of evaluations of this study namely formative evaluation and summative evaluation. After the teaching of each unit was done, the quiz was administered to students to verify their understanding as a formative evaluation. The scores were analyzed and the results of the analysis were employed for improving the lesson plans in the nest unit. The post-test was used as a tool for summative evaluation .The scores of summative evaluation were used to analyze for checking the students 'learning achievement and 
satisfaction of leaning through the developed the lesson plans on of Calculus for Engineering 1 subject on differentiation of algebraic functions based on the theory of multiple intelligences and TAI cooperative learning respectively.

\subsection{Data Collection}

After all lesson plans were completely taught, the data were collected from according to the following steps : 1) the researchers administered the learning achievement test (post-test) on differentiation of algebraic functions calculation and the questionnaire about the subjects, and 2) the scores of the tests and questionnaire were statistically analyzed.

\subsection{Data Analysis}

The results of both learning achievement test and questionnaire were gathered and analyzed through statistically software to find out the results of the learning achievement and satisfaction of learning through the developed the lesson plans of Calculus for Engineering 1 subject on differentiation of algebraic functions calculation based on the theory of multiple intelligences and TAI cooperative learning .

\section{RESULT}

The results of this study were as follows:

The results of the comparison of pre and post-tests scores of learning through the learning activity developed by integrating the theory of multiple intelligences and TAI cooperative learning is shown in the Table 1.

Table 1 The comparison of pre- and post-tests scores

\begin{tabular}{|c|c|c|c|c|c|}
\hline Test & $\mathrm{n}$ & $\overline{\mathrm{x}}$ & S.D. & $\mathrm{t}$ & Sig. \\
\hline Pre - Test & 41 & 11.29 & 2.36 & \multirow{2}{*}{20.53} & 0.00 \\
\hline Post - Test & 41 & 31.29 & 5.53 & & \\
\hline
\end{tabular}

Table 1 presented the mean score of pre-test of learning through the learning activity developed by integrating the multiple intelligences theory and TAI cooperative learning which was 11.29 while the mean score of post-test was 31.29 respectively. This obviously shows that the mean score of post-test was significantly higher than pre-test at the level of .05.

The results of the evaluation of students 'satisfaction on learning through the developed lesson plans on of Calculus for Engineering 1 subject on differentiation of algebraic functions based on the theory of multiple intelligences and TAI cooperative learning are shown in table 2 below:

Table 2 The students 'satisfaction on learnings

\begin{tabular}{|c|l|c|c|c|}
\hline No. & \multicolumn{1}{|c|}{ Statements } & $\bar{x}$ & S.D. & Interpretation \\
\hline 1 & $\begin{array}{l}\text { I like the learning atmosphere that students could } \\
\text { be able to participate in learning process }\end{array}$ & 4.45 & 0.552 & High \\
\hline 2 & $\begin{array}{l}\text { I like the learning atmosphere that promoting } \\
\text { students' responsibility }\end{array}$ & 4.35 & 0.530 & High \\
\hline 3 & $\begin{array}{l}\text { I like the learning atmosphere that helped improve } \\
\text { students' enthusiasm }\end{array}$ & 4.76 & 0.585 & Highest \\
\hline 4 & $\begin{array}{l}\text { I like the learning atmosphere that allowed } \\
\text { students to ask and answer questions, discuss, and } \\
\text { ask for suggestions from teacher. }\end{array}$ & 4.82 & 0.448 & Highest \\
\hline \multicolumn{2}{|l|}{ Mean score of learning atmosphere aspect } & 4.61 & 0.26 & Highest \\
\hline 1 & $\begin{array}{l}\text { I like the learning activity which is suitable with } \\
\text { my ability }\end{array}$ & 4.53 & 0.508 & High \\
\hline 2 & $\begin{array}{l}\text { I like the learning activity which allows students } \\
\text { to share their ideas in classroom }\end{array}$ & 4.62 & 0.595 & High \\
\hline
\end{tabular}




\begin{tabular}{|c|c|c|c|c|}
\hline 3 & $\begin{array}{l}\text { I like the learning activity which promote thinking } \\
\text { and decision making }\end{array}$ & 4.51 & 0.711 & Highest \\
\hline 4 & $\begin{array}{l}\text { I like the learning activity which promotes } \\
\text { confidence }\end{array}$ & 4.51 & 0.597 & Highest \\
\hline 5 & $\begin{array}{l}\text { I like the learning activity which allows students } \\
\text { to learn from multiple ways }\end{array}$ & 4.83 & 0.495 & Highest \\
\hline 6 & $\begin{array}{l}\text { I like the learning activity which allows to present } \\
\text { knowledge in multiple ways }\end{array}$ & 4.61 & 0.542 & Highest \\
\hline 7 & $\begin{array}{l}\text { I like the learning activity which allows students } \\
\text { to use their aptitude in learning }\end{array}$ & 4.61 & 0.494 & Highest \\
\hline & Mean score of learning activities aspect & 4.60 & 0.28 & High \\
\hline \multicolumn{5}{|c|}{ Utilizing of Knowledge } \\
\hline 1 & $\begin{array}{l}\text { I think that I can apply the knowledge that I } \\
\text { learned in daily life }\end{array}$ & 4.78 & 0.475 & Highest \\
\hline 2 & $\begin{array}{l}\text { I think that the knowledge that I learned will help } \\
\text { me work successfully }\end{array}$ & 4.55 & 0.708 & High \\
\hline 3 & $\begin{array}{l}\text { I think that the knowledge that I learned can be } \\
\text { applied for learning in other subjects }\end{array}$ & 4.67 & 0.581 & Highest \\
\hline 4 & $\begin{array}{l}\text { I think that the knowledge that I learned will help } \\
\text { me be able to work individually }\end{array}$ & 4.56 & 0.594 & Highest \\
\hline 5 & $\begin{array}{l}\text { I think that the knowledge that I learned will help } \\
\text { me work as teamwork }\end{array}$ & 4.80 & 0.401 & Highest \\
\hline & Mean score of utilizing of knowledge aspect & 4.67 & 0.552 & Highest \\
\hline & Total & 4.63 & 0.18 & Highest \\
\hline
\end{tabular}

Table 2 shows that the mean score of the students 'satisfaction on learning through the developed the lesson plans of Calculus for Engineering 1 subject on differentiation of algebraic functions based on the theory of multiple intelligences and TAI cooperative learning was 4.63 which was the highest level. When considering each aspect, it was found that the mean score of learning atmosphere aspect was 4.61, the mean score of learning activities aspect was 4.60 and the mean score of Utilizing of Knowledge aspect was 4.67 respectively.

\section{DISCUSSION}

The results of the study revealed that the mean score of pre-test of learning through the learning activity developed by integrating the multiple intelligences theory and TAI cooperative learning which was 11.29 while the mean score of post-test was 31.29 respectively. This obviously shows that the mean score of the post-test was significantly higher than pre-test at the level of .05 . This might be due to the fact that learning through the integration of the theory of multiple intelligences and TAI cooperative learning helped students to improve their learning via multiple ways of teaching and learning (using all 9 intelligences). The students could learn in the way that they prefer as a main approach, while the other less preferable ways of teaching might be the beneficial support of their learning. Moreover, they could use multiple ways to present their knowledge such as song mind map, pictures instead of using only writing work in the traditional classroom.

Moreover, working in group under both interpersonal intelligence and TAI cooperative learning also helped students to learn effectively since they can help explaining, sharing ideas, or discussing for finding the answer and solving problems in learning. When they feel satisfied or comfortable in learning, the results of learning are higher as well. This corresponds with the study of Sulaiman et.al. (2010) who stated that effective teaching of mathematics does not depend on a fixed structure of instructional strategy but involves lively and interactive two-way process in which students play an active part by answering questions and engage in discussions, explaining and demonstrating their methods to others in the class where a rich set of teaching strategies is required from the teachers to ensure the effectiveness of the lesson. Moreover, the success of the integration of theory of multiple intelligences with the TAI cooperative learning for teaching mathematics in this study was supported by the study of Serin et.al. (2009) who proposed that teachers should be aware that there is no single and absolute method in 
any teaching and learning process. Regarding what has been discussed, these were the reasons why the developed lesson plans based on the integration of the theory of multiple intelligences with the TAI cooperative learning could help students get the higher learning achievement.

The mean score of the students' satisfaction on learning through the developed the lesson plans on of Calculus for Engineering 1 subject on differentiation of algebraic functions basing on the theory of multiple intelligences and TAI cooperative learning was 4.61 which was the highest level. This might be the fact that the developed lesson plan and learning activities encouraged students to learn happily and effectively since there were multiple ways of both teaching, learning, and presenting knowledge are well-designed to serve the different needs and aptitudes of students. When they had a chance to learn in the manners that they like, they could learn happily and effectively. Due to the high satisfaction of students in learning, it encouraged to learn effectively and actively since they have multiple ways wo learn and to express their understanding. This was supported by the study of Haley (2004) who mentioned that students in the experimental classes were more enthusiastic about learning and behavior problems were minimized. Teachers felt that their classroom management skills were enhanced. One surprising result of the MI study was the affective outcome that most students expressed positive feelings about teachers using a variety of instructional strategies as well as assessment practices that addressed the multiple intelligences.

\section{SUGGESTION}

Regarding the results of this study, the researchers would like to present the suggestion for both utilization and further study as follows:

\section{Suggestion for utilizing the results of study}

1. Teaching through the integration of both the theory of multiple intelligences and TAI is quite different from traditional way that almost all students are familiar with, the teacher who would like to adopt this teaching activity should, therefore, use the first hour of teaching explain the process of teaching and learning to help students understand the learning process and reduce problems in learning.

2. Since the teachers try to integrate all 9 intelligences in both teaching and learning, this might cause some problems for some students in creating individual work. The teachers who would like to adopt this teaching activities should, consequently, adapt the activities basing on the individual differences of the target students.

\section{Suggestions for the further study}

1. The study of implementing the theory of multiple intelligences and TAI cooperative learning should be done with the other mathematics subject not only calculus such as mathematics for business to see whether the results will be similar as in this study.

2. Since most of the subjects in this study were male students, there should be the study on implementing the theory of multiple intelligences and TAI cooperative learning with the class that has a lot of female students to see whether the results will be similar as in this study.

3. Since there are 9 different intelligences regarding the multiple intelligence theory, to use all of them for teaching one subject might be difficult. So, there should be the study that investigates the suitable intelligences that are suitable for mathematics learning.

\section{ACKNOWLEDGEMENT}

We would like to sincerely thanks all reviewers for the valuable and creative comments for improving the quality of the paper. Our appreciation also goes to Mr. Jonathan Wary for his assistance in editing the language usage in the paper.

\section{REFERENCES}

Adams, J., \& Slater, T. (2002). Learning through sharing. Journal of College Science Teaching, 31(6), 384.

Ball, I., \& Perry, C. (2009). An exploration of individual differences in teachers' temperaments and multiple intelligence. Problems of Education in the 21st Century, 18(18), 21-32.

Bullough, R. V. (2011). Hope, happiness, teaching, and learning. In New Understandings of Teacher's Work (pp. 15-30). Springer, Dordrecht.

Delaney, C. J., \& Shafer, F. K. (2007). Teaching to multiple intelligences by following a "slime trail". Middle School Journal, 39(1), 38-43. 
Ezeh, N. G., Anidi, O. C., \& Nwokolo, B. O. (2021). Body language as a communicative aid amongst language impaired students: Managing disabilities. English Language Teaching, 14(6), 125-134.

Galton, M. \& Eggleston, J., (1979). Some characteristics of effective science teaching. International Journal of Science Education, 1(1), 75-86.

Gardner, H. (1996). Probing more deeply into the theory of multiple intelligences. NaSSP Bulletin, 80(583), 1-7.

Haley, M. H. (2004). Learner-centered instruction and the theory of multiple intelligences with second language Learners. Teachers College Record, 106(1), 163-180.

Jones, S., \& Tanner, H. (2002). Teachers' interpretations of effective whole-class interactive teaching in secondary mathematics classrooms. Educational Studies, 28(3), 265-274.

Keawchuer, S. (2014). Factors affecting happiness learning of students of Faculty of Management Science, Suan Sunandha Rajabhat University. International Journal of Economics and Management Engineering, 8(6), $1790-1794$.

Lash, M. D. (2004). Multiple intelligences and the search for creative teaching. Paths of Learning, 22, 13-15.

Peysner, K. (2021). The benefits of group-learning and information-sharing. BDJ Team, 8(6), 8-10.

Prachagool, V., Nuangchalerm, P., Subramaniam, G., \& Dostal, J. (2016). Pedagogical decision making through the lens of teacher preparation program. Journal for the Education of Gifted Young Scientists, 4(1), 4152.

Serin, N. B., Serin, O., Yavuz, M. A., \& Muhammedzade, B. (2009). The relationship between the primary teachers' teaching strategies and their strengths in multiple intelligences (Their multiple intelligence types)(Sampling: Izmir and Lefkosa). Procedia-Social and Behavioral Sciences, 1(1), 708-712.

Sulaiman, S. (2011). Application of multiple intelligences teaching approach in classroom instruction (Doctoral dissertation, Universiti Putra Malaysia).

Sulaiman, T., Abdurahman, A. R., \& Rahim, S. S. A. (2010). Teaching strategies based on multiple intelligences theory among science and mathematics secondary school teachers. Procedia-Social and Behavioral Sciences, 8, 512-518. 